Article

\title{
Parameterization of Spectral Particulate and Phytoplankton Absorption Coefficients in Sognefjord and Trondheimsfjord, Two Contrasting Norwegian Fjord Ecosystems
}

\author{
Veloisa J. Mascarenhas * (10) and Oliver Zielinski \\ Institute for Chemistry and Biology of the Marine Environment, University of Oldenburg, Schleusenstrasse 1, \\ 26382 Wilhelmshaven, Lower Saxony, Germany; oliver.zielinski@uni-oldenburg.de \\ * Correspondence: veloisa.john.mascarenhas@uni-oldenburg.de; Tel.: +49-(0)-4421-944-181
}

Received: 1 May 2018; Accepted: 18 June 2018; Published: 20 June 2018

check for updates

\begin{abstract}
We present here parameterizations of particulate and phytoplankton absorption coefficients as functions of pigment concentrations (Tchla) in Sognefjord and Trondheimsfjord along the northwestern coast of Norway. The total particulate and non-algal optical densities were measured via quantitative filter technique $(\mathrm{QFT})$ in a spectrophotometer with integrating sphere. The spectral parameter coefficients $\mathrm{A}(\lambda)$ and $\mathrm{E}(\lambda)$ of the power law describing variations of particulate and phytoplankton absorption coefficients as a function of Tchla, were not only different from those provided for open ocean case 1 waters, but also exhibited differences in the two fjords under investigation. Considering the influence of glacial meltwater leading to increased inorganic sediment load in Sognefjord we investigate differences in two different parameterizations, developed by excluding and including inner Sognefjord stations. Tchla are modelled to test the parameterizations and validated against data from the same cruise and that from a repeated campaign. Being less influenced by non-algal particles parameterizations performed well in Trondheimsfjord and yielded high coefficients of determination $\left(\mathrm{R}^{2}\right)$ of modelled vs. measured Tchla. In Sognefjord, the modelled vs. measured Tchla resulted in better $\mathrm{R}^{2}$ with parameter coefficients developed excluding the inner-fjord stations influenced by glacial meltwater influx.
\end{abstract}

Keywords: inherent optical properties; non-algal; ocean color; bio-optics; quantitative filter technique; coastal waters; high latitude; remote sensing; case 2; model

\section{Introduction}

The inherent optical properties (IOPs), i.e., the absorption a $(\lambda)$ and back scattering $b_{b}(\lambda)$ coefficients of the optically active constituents (OACs) govern the diffuse reflectance $R_{r s}(\lambda)$ above water, through a relationship of the form,

$$
R_{r s}(\lambda)=F \frac{b_{b}(\lambda)}{a(\lambda)+b_{b}(\lambda)}
$$

established via studies of radiative transfer [1]. The parameter $F$ depends on the geometrical structure of the incident light field [2]. Bio-optical models developed for predicting underwater light field or interpreting ocean color imageries require the bulk IOPs to be expressed in terms of contributions of individual OACs as functions of their content in seawater, represented in Equation (2):

$$
a(\lambda)=a_{w}(\lambda)+a_{p}(\lambda)+a_{c d o m}(\lambda)
$$


where $a_{w}(\lambda)$ refers to absorption by water molecules, $a_{p}(\lambda)$ to absorption by total particulate, and $a_{\text {cdom }}(\lambda)$ to absorption by colored dissolved organic matter (CDOM). The total particulate absorption spectrum, influenced by phytoplankton pigments, $a_{\text {phy }}(\lambda)$ and non-algal particles (NAP), $a_{\text {nap }}(\lambda)$ is represented as,

$$
a_{p}(\lambda)=a_{p h y}(\lambda)+a_{\text {nap }}(\lambda)
$$

Absorption by non-algal particles is reported to have a spectral shape similar to CDOM, decreasing exponentially with increase in wavelength. However the spectral slope is known to vary [3,4]. In contrast, phytoplankton absorption spectra exhibit more variability both in magnitude and spectral characteristics, being influenced by factors such as pigment composition, light levels, cell size, and package effects [5].

Accurate retrieval of bio-optical parameters from satellite-recorded radiance signals requires bio-optical models that are developed from a detailed understanding of the spectral IOPs of water constituents specific to the region of interest. In semi-analytical algorithms bio-optical models of each of these individual components are essential. In case 1 waters, these properties are strongly linked to phytoplankton and so bio-optical models are least influenced by the other constituents. Case 2 water optical properties however are affected by varying concentrations of terrestrially derived dissolved and particulate matter that do not necessarily co-vary with phytoplankton or each other. Therefore, case 1 water algorithms perform poor or fail when applied to case 2 waters [6].

Moreover, bio-optical properties of water are known to vary from low- and mid-latitude to high-latitude waters $[7,8]$. Most of the empirical ocean color remote sensing algorithms are based on in situ data collected from low and mid latitude waters, restricting their application in high latitude waters [6]. Remote sensing ocean color algorithms in high-latitude coastal waters have also been reported to perform poorly [9]. This necessitates in situ observations and local, region-specific parameterizations of bio-optical algorithms for accurate retrievals of biogeochemical parameters $[9,10]$. Satellite retrievals of biogeochemical parameters via semi-analytical algorithms involving absorption and scattering coefficients have resulted in better estimates [11,12]. Absorption coefficients of phytoplankton have been proved more efficient in estimating ocean primary production than chlorophyll-a concentration (Chla) [13].

Being influenced by marine and glacial meltwater inputs, fjordal ecosystems present bio-optical variability along the fjord transects, from outer to mid to inner fjord sections [14]. Norwegian fjords and coastal waters are highly productive both as natural ecosystems and for aquaculture purposes [15]. However, regular occurrences of harmful algal blooms (HABs) in the Norwegian coastal waters have been of environmental concern [16]. Sognefjord and Trondheimsfjord are both located on the coast of mid Norway. Sognefjord is the longest and the deepest fjord in Norway, receiving significant glacial meltwater discharge, upstream. Trondheimsfjord, rich in marine life, is Norway's third longest fjord. The bio-optical diversity of the two fjord ecosystems under investigation is reported in [17]. With an aim to improve satellite-based monitoring of the fjordal ecosystems we developed essential local parameters for accurate retrieval of ocean color variables. We present here the spectral variability in the relationship of $a_{p}(\lambda)$ and $a_{p h y}(\lambda)$ w.r.t pigment concentrations (Tchla) in two contrasting fjord ecosystems, Sognefjord and Trondheimsfjord, with the following objectives.

1. Investigate the variability in OACs and particulate absorption coefficients

2. Assess the relative contribution of phytoplankton $\left(a_{\text {phy }}(\lambda)\right)$ and non-algal particles $\left(\left(a_{\text {nap }}(\lambda)\right)\right.$ to total absorption $\left(a_{p}(\lambda)\right)$.

3. Analyze trends in the variability of total particulate and phytoplankton absorption coefficients against Tchla in Sognefjord and Trondheimsfjord.

4. Develop and test fjord-specific parameterizations of particulate and phytoplankton absorption coefficients as functions of Tchla.

5. Investigate the bio-optical evidences of possible phytoplankton package effects and determine contributions of accessory pigments from phytoplankton. 


\section{Materials and Methods}

\subsection{Sample Collection}

Samples were collected onboard the German research vessel Heincke during the cruises HE448 and HE491 in Sognefjord and Trondheimsfjord along the northwestern Norwegian coast (Figure 1) in summer 2015 and 2017 respectively. The cruise tracks and physical oceanography data are available via Pangaea [18-21]. Sampling stations in the two fjords during the HE448 cruise are illustrated in Figure 2. Near-surface water samples were obtained using a Ferry Box system (4H JENA: Jena, Germany) with intake at a depth of $4 \mathrm{~m}$. The depth is located well within the first optical depth (FOD) for applicability in ocean color remote sensing algorithms. Acronyms, abbreviations and symbols are listed in Table 1.

Table 1. Acronyms, abbreviations, and symbols.

\begin{tabular}{|c|c|c|}
\hline Acronyms, Abbreviations and Symbols & Unit & Description \\
\hline HE448 (Pangaea ID) & & RV Heincke-cruise 448 \\
\hline HE491 (Pangaea ID) & & RV Heincke-cruise 491 \\
\hline OACs & & optically active constituents \\
\hline AOPs & & apparent optical properties \\
\hline IOPs & & inherent optical properties \\
\hline Chla & $\mathrm{mg} \mathrm{m}^{-3}$ & chlorophyll-a \\
\hline Tchla & $\mathrm{mg} \mathrm{m}^{-3}$ & $\begin{array}{l}\text { sum of chlorophyll-a and } \\
\text { phaeopigment concentration }\end{array}$ \\
\hline CDOM & & colored dissolved organic matter \\
\hline NAP & & non-algal particulates \\
\hline TSM & $\mathrm{mg} \mathrm{L}^{-1}$ & total suspended matter \\
\hline ISM & $\mathrm{mg} \mathrm{L}^{-1}$ & inorganic suspended matter \\
\hline FOD & $\mathrm{m}$ & first optical depth \\
\hline$R_{r s}$ & $\mathrm{sr}^{-1}$ & remote sensing reflectance \\
\hline$a$ & $\mathrm{~m}^{-1}$ & total absorption coefficient \\
\hline$b_{b}$ & $m^{-1}$ & total backscattering coefficient \\
\hline$a_{w}$ & $m^{-1}$ & absorption coefficient of water \\
\hline$a_{p}$ & $\mathrm{~m}^{-1}$ & absorption coefficient of particulate matter \\
\hline$a_{\text {nap }}$ & $\mathrm{m}^{-1}$ & absorption coefficient of non-algal particulates \\
\hline$S_{\text {nap }}$ & $\mathrm{nm}^{-1}$ & slope coefficient of non-algal particulates \\
\hline$a_{p h y}$ & $\mathrm{~m}^{-1}$ & absorption coefficient of phytoplankton \\
\hline$a_{c d o m}$ & $\mathrm{~m}^{-1}$ & absorption coefficient of CDOM \\
\hline$a_{p h y}^{*}$ & $\mathrm{~m}^{2} \mathrm{mg}^{-1}$ & $\begin{array}{l}\text { pigment-specific phytoplankton } \\
\text { absorption coefficient }\end{array}$ \\
\hline$A_{p}$ & & power law coefficient in $a_{p}$ vs. Tchla \\
\hline$E_{p}$ & & power law coefficient in $a_{p}$ vs. Tchla \\
\hline$A_{\text {phy }}$ & & power law coefficient in $a_{p h y}$ vs. Tchla \\
\hline$E_{\text {phy }}$ & & power law coefficient in $a_{p h y}$ vs. Tchla \\
\hline
\end{tabular}




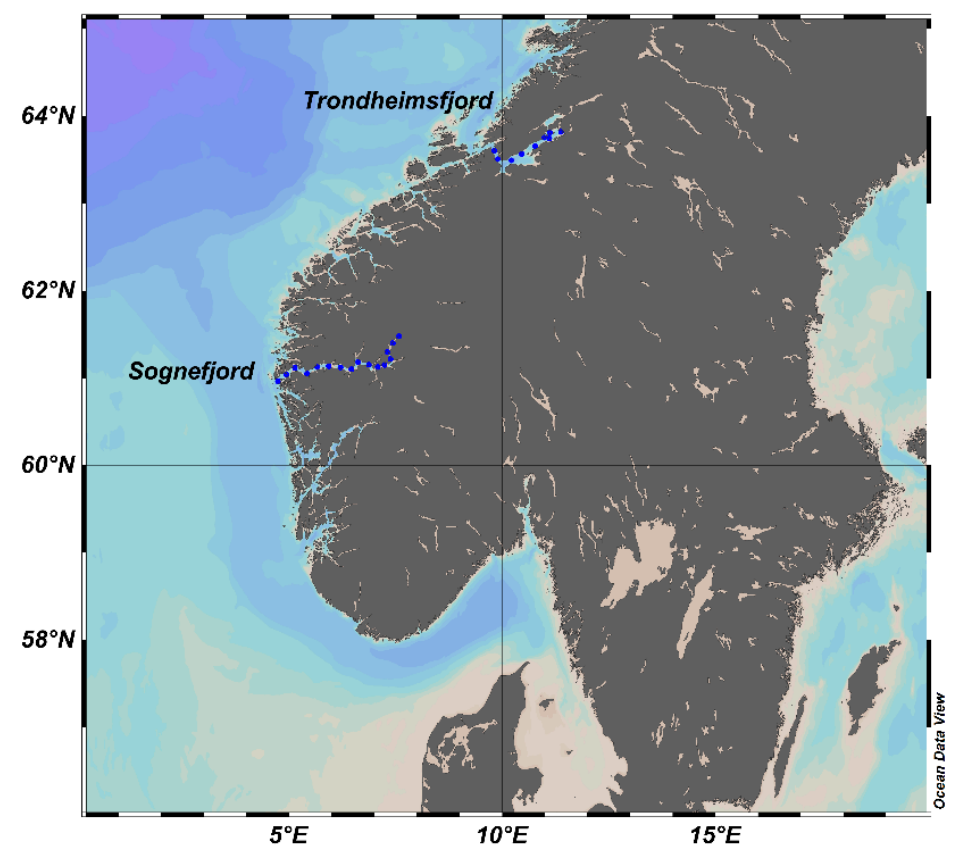

Figure 1. Sognefjord and Trondheimsfjord, along the northwestern coast of Norway. Blue dots indicate the stations sampled in summer 2015, cruise ID HE448.
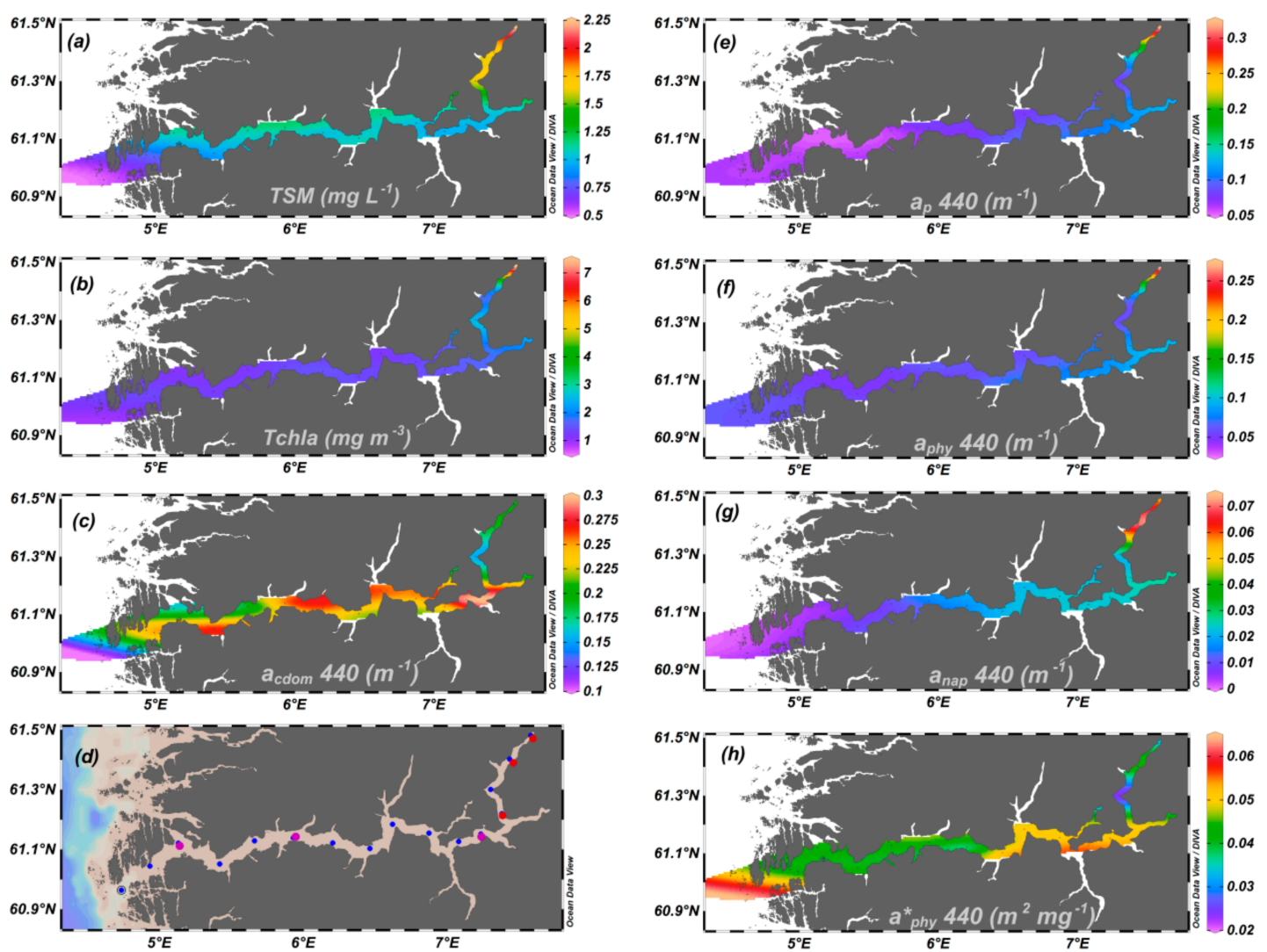

(A)

Figure 2. Cont. 

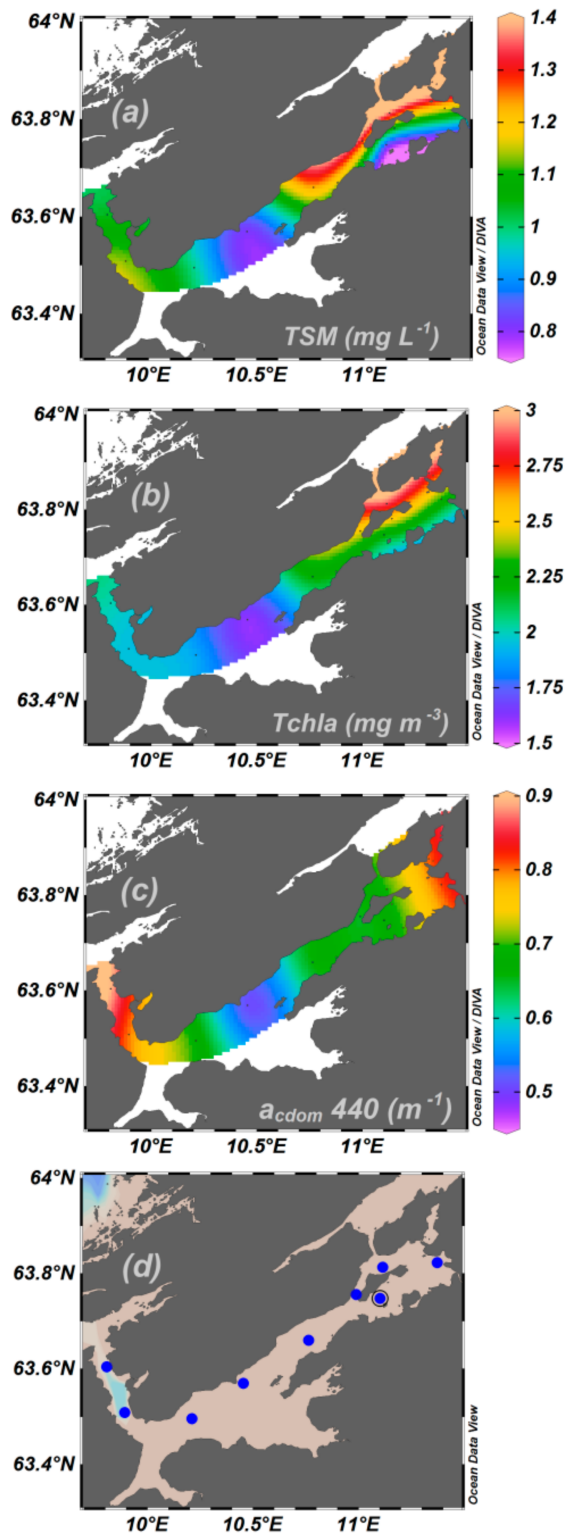
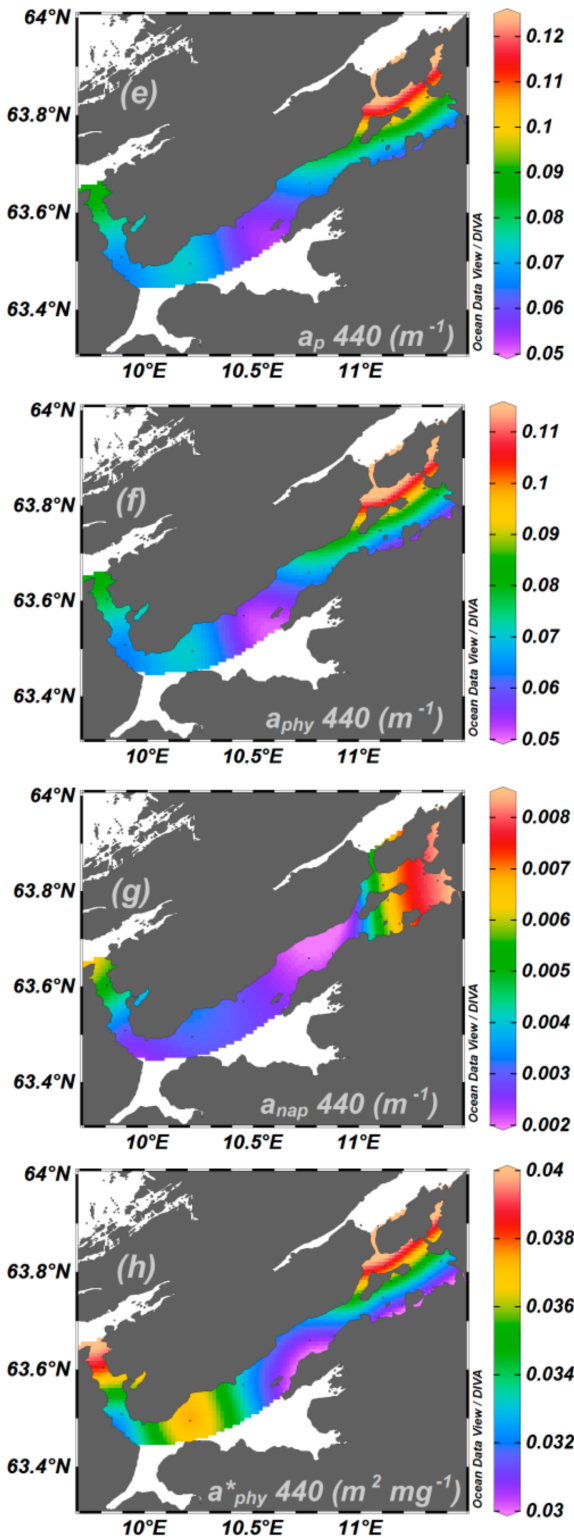

(B)

Figure 2. (A) Near surface optically active constituent (OAC) concentrations and absorption coefficients in Sognefjord. (a) total suspended matter concentration (TSM), (b) pigment concentration (Tchla), (c) colored dissolved organic matter (CDOM), (e) total particulate $\mathrm{a}_{\mathrm{p}} 440$, (f) phytoplankton $\mathrm{a}_{\text {phy }} 440$, (g) non-algal $\mathrm{a}_{\text {nap }} 440$, (h) pigment-specific phytoplankton $\mathrm{a}^{*}$ phy 440 absorption coefficients at $440 \mathrm{~nm}$. (d) sampling stations in Sognefjord $(N=16)$. ( $N$ : number of sampled stations). (B) Near surface OAC concentrations and absorption coefficients in Trondheimsfjord. (a) total suspended matter concentration (TSM), (b) pigment concentration (Tchla), (c) colored dissolved organic matter CDOM, (e) total particulate $\mathrm{a}_{\mathrm{p}} 440$, (f) phytoplankton $\mathrm{a}_{\text {phy }} 440$, (g) non-algal $\mathrm{a}_{\text {nap }} 440$, (h) pigment-specific phytoplankton $\mathrm{a}^{*}$ phy 440 absorption coefficients at $440 \mathrm{~nm}$. (d) sampling stations in Trondheimsfjord $(N=9)$. (N: number of sampled stations).

\subsection{Determination of $O A C$ Concentrations}

Water samples of varying volumes were filtered for quantitative analysis of phytoplankton pigment, total suspended matter (TSM), and inorganic suspended matter (ISM) concentrations. For Chla and phaeopigment (phaeo) analysis, 0.5-3.5 L of sample volumes were filtered onboard in 
duplicate through $0.7 \mu \mathrm{m}$ glass fiber filters (Whatman GF/F) under low vacuum. Throughout the filtration, the funnels were covered with aluminium foil to reduce any possible influence of ambient light on the sample. Following filtration, the filters were stored in vials and frozen onboard at $-80^{\circ} \mathrm{C}$ until further analysis in laboratory. Chla and phaeo concentrations were calculated according to EPA method 445 using fluorometry (Turner Designs, Park Holliston, MA, USA). The sum of chlorophyll a and phaeopigment concentrations is referred to as Tchla throughout this study.

For estimation of TSM and ISM, 2.0-8.0 L of water samples (triplicates) were filtered onboard through $0.7 \mu \mathrm{m}$ pre-combusted and pre-weighed (Kern 770-60, KERN \& SOHN GmbH: Balingen, Germany) glass fiber filters (Whatmann GF/F) and frozen at $-20^{\circ} \mathrm{C}$. Post cruise, the filters were dried at $60^{\circ} \mathrm{C}$ for at least $6 \mathrm{~h}$ and weighed for TSM content; subsequently, the sample filters were combusted at $500{ }^{\circ} \mathrm{C}$ for $5 \mathrm{~h}$ and weighed again for inorganic fraction (ISM) of the total suspended matter [22].

Absorbance, Abs $(\lambda)$, by CDOM was measured in a double beam UV-VIS-Spectrophotometer (UV-2700, Shimadzu: Kyoto Prefecture, Japan) using $10 \mathrm{~cm}$ cuvettes with ultrapure water (Milli-Q $>18.2 \mathrm{M} \Omega$ ) as reference. Spectral absorption coefficients $a_{\text {cdom }}(\lambda)$ were then calculated following Equation (4)

$$
\mathrm{a}_{\mathrm{cdom}}(\lambda)=\frac{2.303 \times \operatorname{Abs}(\lambda)}{1}
$$

where $l$ represents the pathlength in meters.

\subsection{Particulate Absorption Measurements}

Absorption coefficients of total particulate $a_{p}(\lambda)$ and non-algal $a_{\text {nap }}(\lambda)$ fractions were determined using the quantitative filter technique (QFT). Optical density of filters was measured using a spectrophotometer with integrating sphere (Cary 5000, Agilent Technologies, Santa Clara, CA, USA). Spectral absorption coefficients for particulate and the non-algal fractions were then calculated following Equation (5) as per IOCCG protocols [23]:

$$
a_{x}(\lambda)=\frac{\left\{\ln (10) \times 0.323 \times\left[O D_{f}(\lambda)\right]^{1.0867}\right\}}{V} \times \text { area }
$$

where $x$ refers to either the total particulate or the non-algal particulate fraction. $O D_{f}(\lambda)$ represents the blank corrected and averaged sample filter optical density, area, the effective area of filter in $\mathrm{m}^{2}$, 1.0867 , the amplification factor, and $V$, the sample volume filtered in $\mathrm{m}^{3}$. Phytoplankton absorption coefficients were then derived as the difference between total particulate and non-algal absorption coefficients. Detailed sample analysis is presented in [17]. The $a_{p}(\lambda)$ and $a_{\text {nap }}(\lambda)$ data are published and accessible via the Pangaea database [24].

\section{Results}

\subsection{Variability in $O A C s$ and Absorption Coefficients}

The near-surface concentrations of OACs and absorption coefficients along transects in Sognefjord and Trondheimsfjord are illustrated in Figure 2, respectively. The Tchla concentrations ranged from 0.96 to $7.45 \mathrm{mg} \mathrm{m}^{-3}$ in Sognefjord with lowest concentration in the outer fjord and highest in the inner-fjord. In Trondheimsfjord, the Tchla concentrations ranged from $1.59-2.92 \mathrm{mg} \mathrm{m}^{-3}$. TSM concentrations were also higher in Sognefjord than in Trondheimsfjord. In Sognefjord the TSM concentrations ranged from 0.55 to $2.23 \mathrm{mg} \mathrm{L}^{-1}$, while in Trondheimsfjord the concentrations varied from 0.80 to $1.40 \mathrm{mg} \mathrm{L}^{-1}$. The percentage of inorganic matter in TSM ranged from 39 to $73 \%$ in Sognefjord, with highest levels at the inner Sognefjord stations. In Trondheimsfjord the range observed was relatively narrow varying from 47 to $53 \%$. All along the fjord transects, $a_{c d o m} 440$ values were higher in Trondheimsfjord than in Sognefjord (Figure 2). In Sognefjord the coefficients varied from 0.12 to $0.30 \mathrm{~m}^{-1}(0.22 \pm 0.46)$, while in Trondheimsfjord, from $0.50-0.90 \mathrm{~m}^{-1}(0.7 \pm 0.11)$. 
The average particulate, dissolved, and pigment-specific phytoplankton absorption spectra in Sognefjord and Trondheimsfjord are presented in Figure 3. The total particulate absorption spectra, $a_{p}(\lambda)$, include contributions from phytoplankton and non-algal particles. Stations with maximum particulate absorption curves corresponded to stations with highest TSM concentrations in the inner-fjord sections [25]. The $a_{p}(\lambda)$ coefficients were higher in Sognefjord than in Trondheimsfjord. In Sognefjord, the coefficients varied over an order of magnitude from 0.053 to $0.315 \mathrm{~m}^{-1}(0.100 \pm 0.061)$ at $440 \mathrm{~nm}$ and from 0.017 to $0.149 \mathrm{~m}^{-1}(0.038 \pm 0.031)$ at $675 \mathrm{~nm}$ with maximum coefficients corresponding to maximum Tchla concentrations in the inner-fjord section. The spectra were similar to those of phytoplankton absorption, with peaks in the blue and red regions in the visible range of the electromagnetic spectra (dominance of phytoplankton) except at one station in the inner Sognefjord where the Chla primary absorption peak was relatively weak. The $a_{p h y}(440)$ also varied over an order of magnitude in Sognefjord from 0.049 to $0.257 \mathrm{~m}^{-1}$.

Sognefjord
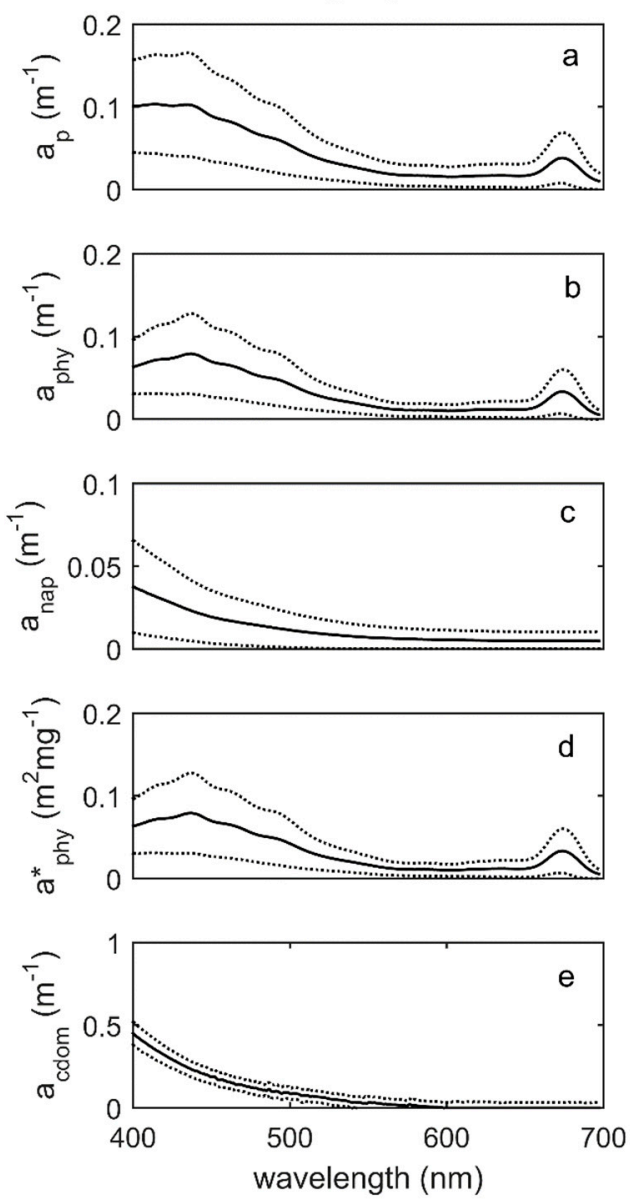

Trondheimsfjord
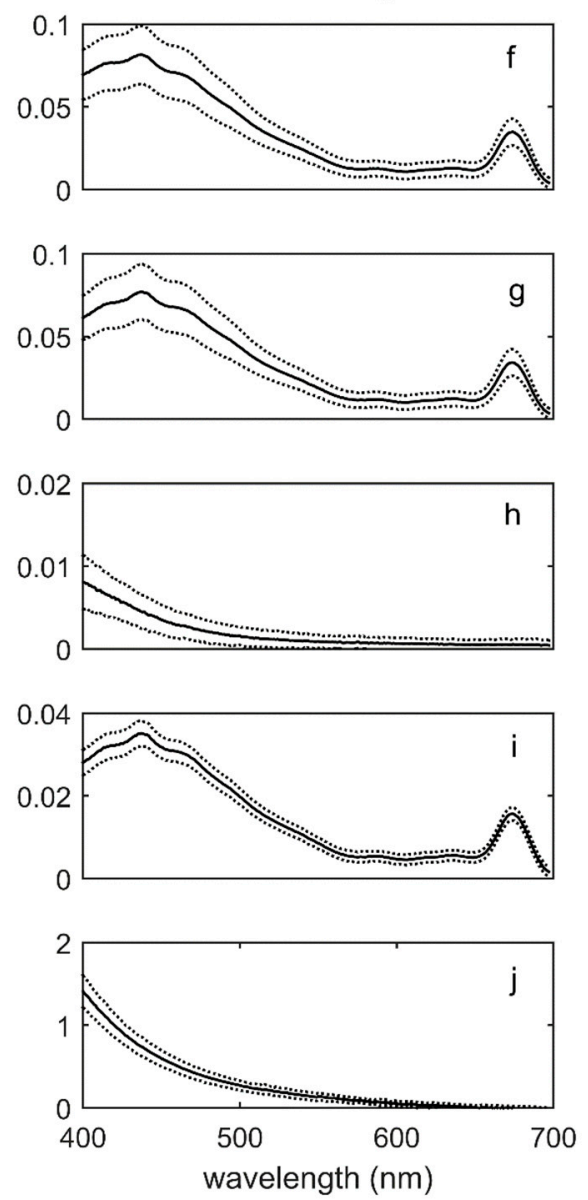

Figure 3. Average absorption spectra (solid lines) with plus/minus one standard deviation (dotted lines) for total particulate $\left(a_{p}\right)$, phytoplankton $\left(a_{p h y}\right)$, non-algal $\left(a_{n a p}\right)$, pigment-specific phytoplankton absorption $\left(a_{\text {phy }}^{*}\right)$ and colored dissolved organic matter $\left(a_{\text {cdom }}\right)$ absorption in Sognefjord $(\mathbf{a}-\mathbf{e}, N=16)$ and Trondheimsfjord $(\mathbf{f}-\mathbf{j}, N=9)$.

In Trondheimsfjord, $a_{p}(440)$ ranged between $0.055-0.121 \mathrm{~m}^{-1}(0.08 \pm 0.017)$ and $a_{p}(675)$ between $0.025-0.054 \mathrm{~m}^{-1}(0.035 \pm 0.008)$. The $a_{p h y}$ (440) coefficients ranged from 0.052 to $0.114 \mathrm{~m}^{-1}$. In general, the $a_{p}(\lambda)$ and $a_{p h y}(\lambda)$ spectra showed little variability in magnitude and shape along the length of the fjord except in the innermost sections of Sognefjord and Trondheimsfjord. An overview of the OAC 
concentrations and the various absorption coefficients is presented in Table 2. For detailed spectral variability in the different absorption coefficients we refer to [25].

Table 2. Range (min-max) of near-surface OAC concentrations and absorption coefficients with Mean and Standard Deviation (Mean \pm SD) in the two campaigns HE448 (2015) and HE491 (2017) in Sognefjord and Trondheimsfjord. (N: number of data points).

\begin{tabular}{cccccccc}
\hline & & Sognefjord & $(\boldsymbol{N}=\mathbf{1 6})$ & & Trondheimsfjord & $(\boldsymbol{N}=\mathbf{9})$ \\
\hline HE448 & unit & Min & Max & Mean \pm SD & Min & Max & Mean \pm SD \\
\hline Tchla & $\mathrm{mg} \mathrm{m}^{-3}$ & 0.96 & 7.45 & $1.87 \pm 1.49$ & 1.59 & 2.92 & $2.18 \pm 0.36$ \\
\hline TSM & $\mathrm{mg} \mathrm{L}^{-1}$ & 0.55 & 2.23 & $1.16 \pm 0.38$ & 0.80 & 1.40 & $1.10 \pm 0.20$ \\
\hline ISM & $\mathrm{mg} \mathrm{L}^{-1}$ & 0.22 & 1.29 & $0.58 \pm 0.29$ & 0.38 & 0.74 & $0.55 \pm 0.12$ \\
\hline$a_{\text {cdom }} 440$ & $\mathrm{~m}^{-1}$ & 0.123 & 0.3 & $0.22 \pm 0.046$ & 0.50 & 0.90 & $0.71 \pm 0.10$ \\
\hline$a_{p} 440$ & $\mathrm{~m}^{-1}$ & 0.053 & 0.314 & $0.1 \pm 0.06$ & 0.055 & 0.121 & $0.080 \pm 0.017$ \\
\hline$a_{\text {phy }} 440$ & $\mathrm{~m}^{-1}$ & 0.049 & 0.257 & $0.078 \pm 0.047$ & 0.052 & 0.114 & $0.076 \pm 0.017$ \\
\hline$a_{\text {nap }} 440$ & $\mathrm{~m}^{-1}$ & 0.003 & 0.071 & $0.022 \pm 0.018$ & 0.002 & 0.008 & $0.004 \pm 0.002$ \\
\hline$a^{*}$ phy 440 & $\mathrm{~m}^{2} \mathrm{mg}^{-1}$ & 0.023 & 0.061 & $0.045 \pm 0.009$ & 0.031 & 0.039 & $0.035 \pm 0.003$ \\
\hline & & Sognefjord & $\mathbf{N}=3)$ & & Trondheimsfjord & $(\boldsymbol{N}=3)$ \\
\hline HE491 & unit & Min & Max & Mean $\pm \mathrm{SD}$ & Min & Max & Mean $\pm \mathrm{SD}$ \\
\hline Tchla & $\mathrm{mg} \mathrm{m}^{-3}$ & 0.4 & 1.17 & $0.78 \pm 0.27$ & 1.04 & 2.49 & $1.76 \pm 0.58$ \\
\hline TSM & $\mathrm{mg} \mathrm{L}^{-1}$ & 0.34 & 1.27 & $0.73 \pm 0.30$ & 0.65 & 0.95 & $0.78 \pm 0.13$ \\
\hline ISM & $\mathrm{mg} \mathrm{L}^{-1}$ & 0.13 & 1.01 & $0.37 \pm 0.28$ & 0.20 & 0.33 & $0.27 \pm 0.05$ \\
\hline
\end{tabular}

\subsection{Relative Contribution of Phytoplankton and Non-Algal Particles to Total Absorption}

The total particulate absorption spectrum constitutes absorption by phytoplankton pigments $\left(a_{\text {phy }}(\lambda)\right)$ and non-algal particles $\left(a_{\text {nap }}(\lambda)\right)$. In Sognefjord, the percentage contribution of the non-algal particulate fraction to total absorption at $440 \mathrm{~nm}$, ranged from 5 to $43 \%$ with maximum contributions in the inner fjord section. In contrast, the percentage contribution of the non-algal particulate fraction amounted to only about 3 to $10 \%$ in Trondheimsfjord and therefore 90 to $97 \%$ contribution from phytoplankton pigments. Non-algal particulate absorption, $a_{n a p}(\lambda)$, spectra measured upon bleaching filters with sodium hypochlorite followed similar exponential decay curves as CDOM absorption spectra, increasing exponentially with decreasing wavelength represented as

$$
a_{\text {nap }}(\lambda)=a_{\text {nap }}\left(\lambda_{0}\right) \times \exp \left(-S_{\text {nap }}\left(\lambda-\lambda_{0}\right)\right)
$$

where $a_{\text {nap }}\left(\lambda_{0}\right)$ refers to non-algal particulate absorption at a reference wavelength in $\mathrm{m}^{-1}$ and $S_{n a p}$ represents the slope of the exponential curve. The average $a_{n a p}$ spectra in Sognefjord and Trondheimsfjord are presented in Figure 3. The spectra exhibited similar spectral shapes, low at the red end of the spectrum, increasing steadily as wavelength decreases into the blue and UV. In Sognefjord the slope coefficients determined over the wavelength range $412-675 \mathrm{~nm}$ varied from $0.006-0.036 \mathrm{~nm}^{-1}$ while in Trondheimsfjord the slope coefficients ranged from $0.007-0.04 \mathrm{~nm}^{-1}$.

The relative contributions of the dissolved and particulate fractions to total absorption at $440 \mathrm{~nm}$ in Sognefjord and Trondheimsfjord are presented using trilinear graphs in Figure 4. CDOM dominated total absorption at $440 \mathrm{~nm}$. However, excluding the contribution of CDOM, i.e., considering particulate fractions alone, absorption by phytoplankton exceeded that by non-algal particles. With an aim to assess the effects of increased Tchla and non-algal particles on the total particulate absorption coefficient at the mentioned stations, we develop two different parameterizations in Sognefjord, one excluding and the other including inner-fjord stations influenced strongly by glacial meltwater influx. 
(a)

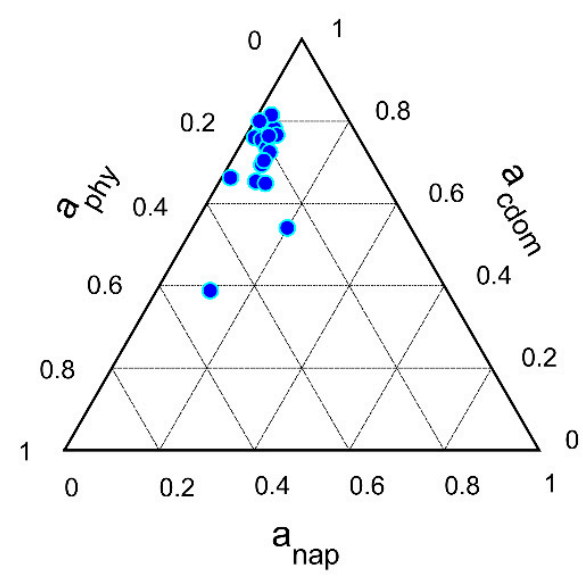

(b)

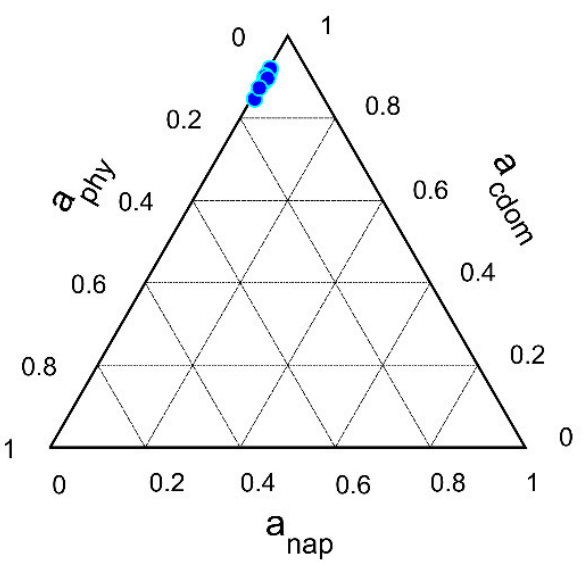

Figure 4. Trilinear graphs illustrating the relative contributions of OACs: phytoplankton $\left(a_{\text {phy }}\right)$, non-algal particles $\left(a_{\text {nap }}\right)$ and CDOM $\left(a_{c d o m}\right)$ to the total absorption coefficient at $440 \mathrm{~nm}$ in Sognefjord (a, $N=16)$ and Trondheimsfjord (b, $N=9$ ). CDOM dominated absorption at $440 \mathrm{~nm}$ in both fjords under investigation. ( $N$ : number of data points).

\subsection{Analyzing Trends in $a_{x}$ vs. Tchla}

The increase in absorption coefficients $a_{p}(\lambda)$ and $a_{p h y}(\lambda)$ with increase in Tchla is well represented by power functions $[3,5]$ of the forms

$$
\begin{gathered}
a_{p}(\lambda)=A_{p}(\lambda) \times[\text { Tchla }]^{E_{p}(\lambda)} \\
a_{p h y}(\lambda)=A_{p h y}(\lambda) \times[\text { Tchla }]^{E_{p h y}(\lambda)}
\end{gathered}
$$

respectively, where $A_{p}(\lambda), A_{\text {phy }}(\lambda), E_{p}(\lambda)$, and $E_{\text {phy }}(\lambda)$ are wavelength-dependent parameters. The variations of $a_{p}(\lambda)$ and $a_{p h y}(\lambda)$ as functions of Tchla at wavelengths corresponding to chlorophyll a (Chla) absorption peaks in the blue and red spectral wavebands are shown in Figure 5. Considering the increased contribution of NAPs (Section 3.2) and Tchla $\left(>1.92 \mathrm{mg} \mathrm{m}^{-3}\right)$, at stations in the inner Sognefjord, we analyzed the relationships following two approaches: one excluding the inner-fjord stations (highlighted in red in Figure 2A) and another including the aforementioned stations. At $443 \mathrm{~nm}$, where $a_{p}(\lambda)$ and $a_{p h y}(\lambda)$ absorb maximum, least squares fit provided the following relationships in Sognefjord (Equations (9) and (10)) and Trondheimsfjord (Equations (13) and (14)). Following the second approach i.e., including the inner Sognefjord stations the relationships were derived as in Equations (11) and (12).

$$
\begin{array}{cc}
a_{p}(440)=0.0597 \times[\text { Tchla }]^{0.9822} & \mathrm{R}^{2}=0.54 \\
a_{p h y}(440)=0.0514 \times[\text { Tchla }]^{0.7832} & \mathrm{R}^{2}=0.57 \\
a_{p}(440)=0.063 \times[\text { Tchla }]^{0.7791} & \mathrm{R}^{2}=0.76 \\
a_{p h y}(440)=0.0509 \times[\text { Tchla }]^{0.7195} & \mathrm{R}^{2}=0.79 \\
a_{p}(440)=0.0325 \times[\text { Tchla }]^{1.1568} & \mathrm{R}^{2}=0.84 \\
a_{p h y}(440)=0.0308 \times[\text { Tchla }]^{1.1566} & \mathrm{R}^{2}=0.85
\end{array}
$$

The exponents $A_{p}, A_{p h y}$ and $E_{p}, E_{p h y}$ obtained for Trondheimsfjord in Equations (13) and (14) matched closely than those obtained for Sognefjord. 


\subsection{Parameterization of $a_{p}(\lambda)$ and $a_{p h y}(\lambda)$ as Functions of Tchla in Sognefjord and Trondheimsfjord}

\subsubsection{Development of Model Parameters}

Considering the increased Tchla and NAP contributions to total absorption coefficients at stations in the inner Sognefjord as discussed in Section 3.2, we developed two different sets of parameterizations for Sognefjord one excluding and another including the inner-fjord stations (highlighted in red in Figure 2A). Spectral values of absorption coefficients $a_{p}(\lambda)$ and $a_{p h y}(\lambda)$ were parameterized using least squares fit for Tchla ranging from 0.96 to $1.92 \mathrm{mg} \mathrm{m}^{-3}$ (excluding the aforementioned inner-fjord stations) in Sognefjord and from 1.59 to $2.92 \mathrm{mg} \mathrm{m}^{-3}$ in Trondheimsfjord. Figure 6 exhibits the spectral behavior of the parameters $A_{p}(\lambda), A_{p h y}(\lambda), E_{p}(\lambda)$, and $E_{p h y}(\lambda)$ in Sognefjord and Trondheimsfjord. The spectral coefficients were not only different than those derived for low and mid latitude waters [5] but were also different in the two fjords under investigation. In Sognefjord, following the first approach, the spectral coefficients $E_{p}(\lambda)$ and $E_{p h y}(\lambda)$ followed similar trends with differences in magnitude. Maximum differences were observed in the wavelength range 500-660 nm. However, following the second approach, i.e., including the inner-fjord stations, reduced the differences in magnitude. In contrast, in Trondheimsfjord, with Tchla ranging from 1.59-2.92 $\mathrm{mg} \mathrm{m}^{-3}$, the exponents $E_{p}(\lambda)$ and $E_{\text {phy }}(\lambda)$ varied closely.

(a)
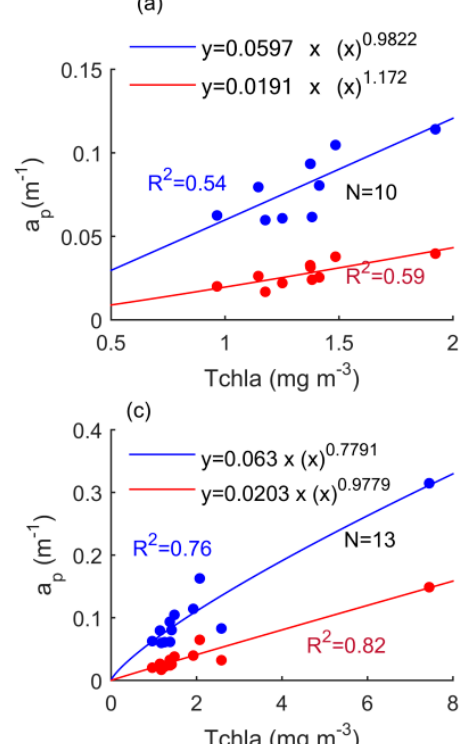

(e)

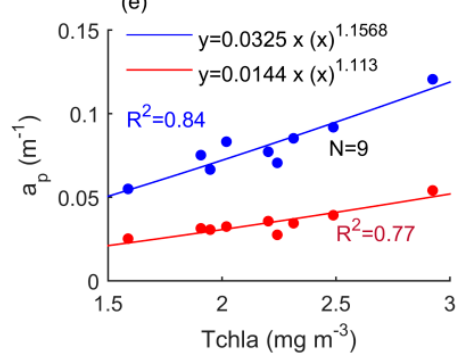

(b)

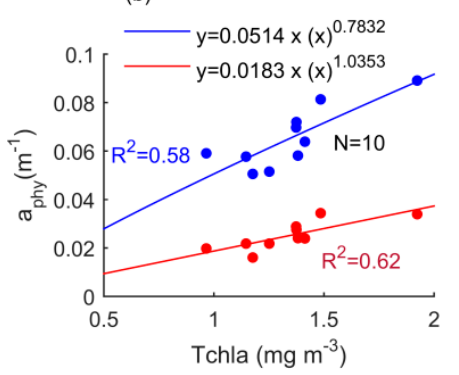

(d)
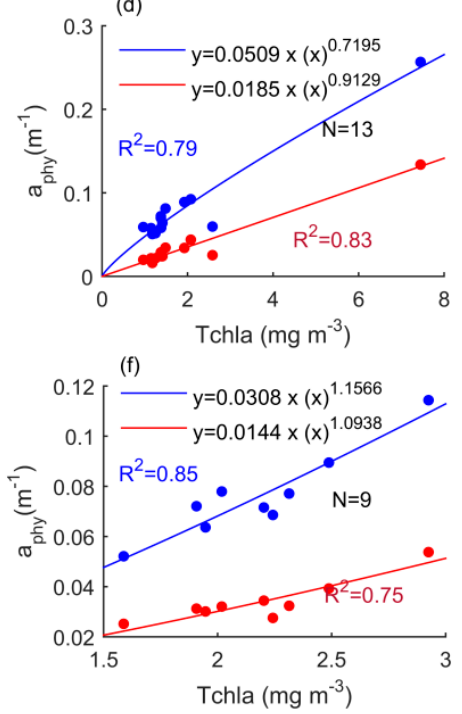

Figure 5. Variations in $(\mathbf{a}, \mathbf{c}, \mathbf{e})$ total particulate $\left(a_{p}\right)$ and $(\mathbf{b}, \mathbf{d}, \mathbf{f})$ phytoplankton $\left(a_{\text {phy }}\right)$ absorption coefficients as a function of pigment concentration (Tchla) at the blue $(440 \mathrm{~nm}$, blue filled circles) and red (675 nm, red filled circles) Chla absorption peaks in Sognefjord (a-d) and Trondheimsfjord (e,f). (a,b) represent trends in Sognefjord corresponding to analysis excluding the inner-fjord stations and (c,d) the trends including the inner-fjord stations. ( $N$ : number of data points; $\mathrm{R}^{2}$ : coefficient of determination). 
(A)
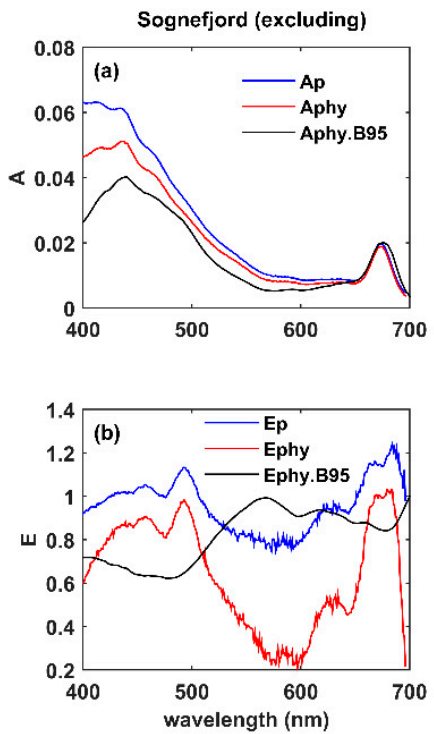

(B)
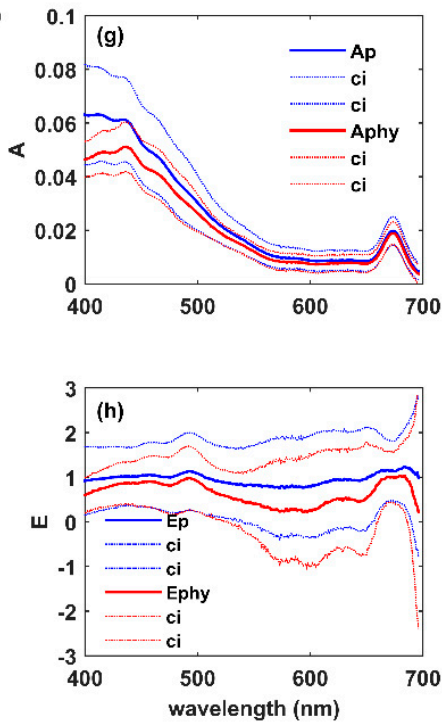
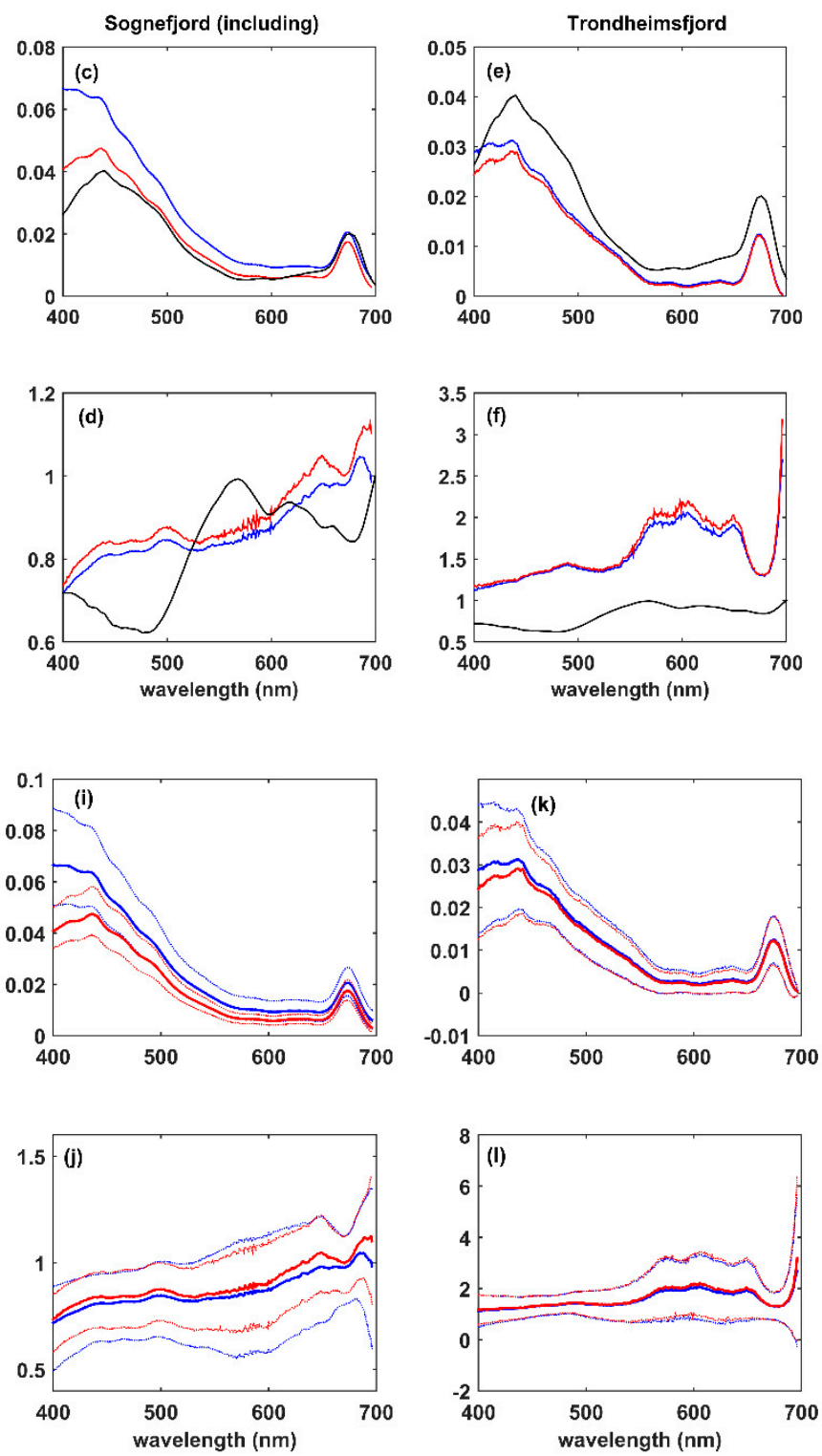

Figure 6. Spectral parameter coefficients $A_{p}, E_{p}$ and $A_{p h y}, E_{p h y}$ in the power functions (Equations (7) and (8)) representing variations of the absorption coefficients $a_{p}(\lambda)$ and $a_{p h y}(\lambda)$ respectively as functions of pigment concentration (Tchla) in Sognefjord and Trondheimsfjord. Spectra represent coefficients developed excluding $(\mathbf{a}, \mathbf{b}, \mathbf{g}, \mathbf{h})$ and including $(\mathbf{c}, \mathbf{d}, \mathbf{i}, \mathbf{j})$ the inner Sognefjord stations and Trondheimsfjord $(\mathbf{e}, \mathbf{f}, \mathbf{k}, \mathbf{l})$. (A) (a, c,e) Spectral coefficients of $A_{p}$ (blue), $A_{p h y}$ (red) in comparison to $A_{\text {phy. }}$. B95 (black) reported for low and mid latitude waters covering Tchla range of $0.02-25.0 \mathrm{mg} \mathrm{m}^{-3}[5]$. $(\mathbf{b}, \mathbf{d}, \mathbf{f})$ Spectral coefficients of $E_{p}$ (blue), $E_{p h y}$ (red) in comparison to $E_{p h y}$. $B 95$ (black) reported for low- and mid-latitude waters covering Tchla range of $0.02-25.0 \mathrm{mg} \mathrm{m}^{-3}$ [5]. (B) Same as in (A) with $95 \%$ confidence intervals (ci). Dotted blue and red spectra correspond to ci of the solid blue and red spectra respectively.

Spectral curves of the parameters $A_{p}(\lambda)$ and $A_{p h y}(\lambda)$ were similar to those of total particulate and phytoplankton absorption spectra respectively in Sognefjord and Trondheimsfjord (Figure 6). In both fjords, the magnitude variability in the $A_{p}(\lambda)$ and $A_{\text {phy }}(\lambda)$ spectra was maximum in the 400-450 nm wavelength domain. The $A_{p}$ and $A_{p h y}$ spectra matched more closely in Trondheimsfjord than in Sognefjord. 


\subsubsection{Validation of Parameterization}

The developed parameterizations were tested at three stations in Sognefjord sampled during the same campaign but not included in the development. Tchla concentrations were estimated at the mentioned three stations from total particulate and phytoplankton absorption coefficients using the developed parameters $A_{p}(\lambda), A_{p h y}(\lambda), E_{p}(\lambda)$, and $E_{p h y}(\lambda)$. The three stations were chosen such that each represents a section of the Sognefjord and are illustrated in red in Figure 2. Since the number of sampling stations was limited in Trondheimsfjord, no validation was performed with stations covered in the campaign.

In addition, Tchla was also estimated from measured absorption coefficients at stations sampled in a repeated campaign (HE491) in both fjords in summer 2017 (http:/ / epic.awi.de/45478/1/HE491_ nav.pdf). Samples in the 2017 campaign were collected at $1 \mathrm{~m}$ and $5 \mathrm{~m}$ depths. The OAC concentrations encountered in the campaign are presented in Table 2. Results of the validation are presented in Table 3. In general, parameterizations developed by excluding the inner-fjord stations yielded similar regression coefficients than the one developed by including the stations. However, the 1:1 $R^{2}$ coefficients were higher excluding the inner-fjord stations. Tchla estimated from particulate absorption coefficients yielded higher coefficients of determination in Sognefjord than those estimated from phytoplankton absorption coefficients. In contrast, in Trondheimsfjord no such differences were observed. Coefficients of determination matched closely for Tchla estimated from $a_{p}(\lambda)$ and $a_{p h y}(\lambda)$.

Table 3. Coefficients of determination obtained for measured vs modelled Tchla tested at representative stations from HE448 (2015) and HE491 (2017) in Sognefjord (excluding and including inner fjord stations) and Trondheimsfjord. (N: number of data points).

\begin{tabular}{|c|c|c|c|c|c|}
\hline \multicolumn{3}{|c|}{ Sognefjord } & \multicolumn{3}{|c|}{ Trondheimsfjord } \\
\hline Tchla Derived from & $\begin{array}{c}R^{2} \text { (Regression) } \\
\quad(N=3)\end{array}$ & $\begin{array}{l}\mathrm{R}^{2}(1: 1) \\
(N=3)\end{array}$ & Tchla Derived from & $\begin{array}{c}\mathrm{R}^{2} \text { (Regression) } \\
\quad(N=3)\end{array}$ & $\begin{array}{l}1: 1 R^{2} \\
(N=3)\end{array}$ \\
\hline \multicolumn{6}{|c|}{ HE448 (excluding inner-fjord stations) } \\
\hline$a_{p} 440$ & 0.76 & 0.67 & $a_{p} 440$ & NA & NA \\
\hline$a_{p h y} 440$ & 0.59 & 0.54 & $a_{p h y} 440$ & NA & NA \\
\hline$a_{p} 675$ & 0.80 & 0.79 & $a_{p} 675$ & NA & NA \\
\hline$a_{\text {phy }} 675$ & 0.67 & 0.66 & $a_{\text {phy }} 675$ & NA & NA \\
\hline \multicolumn{6}{|c|}{ HE491 (excluding inner-fjord stations) } \\
\hline$a_{p} 440$ & 0.70 & 0.69 & $a_{p} 440$ & 0.95 & 0.95 \\
\hline$a_{\text {phy }} 440$ & 0.45 & 0.44 & $a_{p h y} 440$ & 0.95 & 0.92 \\
\hline$a_{p} 675$ & 0.06 & -0.80 & $a_{p} 675$ & 0.83 & 0.67 \\
\hline$a_{p h y} 675$ & 0.99 & 0.95 & $a_{\text {phy }} 675$ & 0.83 & 0.80 \\
\hline \multicolumn{6}{|c|}{ HE448 (including inner-fjord stations) } \\
\hline$a_{p} 440$ & 0.74 & -0.9 & $a_{p} 440$ & NA & NA \\
\hline$a_{p h y} 440$ & 0.59 & -0.45 & $a_{p h y} 440$ & NA & NA \\
\hline$a_{p} 675$ & 0.79 & 0.44 & $a_{p} 675$ & NA & NA \\
\hline$a_{p h y} 675$ & 0.67 & 0.32 & $a_{p h y} 675$ & NA & NA \\
\hline \multicolumn{6}{|c|}{ HE491 (including inner-fjord stations) } \\
\hline$a_{p} 440$ & 0.93 & 0.83 & $a_{p} 440$ & 0.95 & 0.95 \\
\hline$a_{p h y} 440$ & 0.43 & 0.42 & $a_{p h y} 440$ & 0.95 & 0.92 \\
\hline$a_{p} 675$ & 0.99 & 0.165 & $a_{p} 675$ & 0.83 & 0.67 \\
\hline$a_{\text {phy }} 675$ & 0.05 & -1.08 & $a_{p h y} 675$ & 0.83 & 0.80 \\
\hline
\end{tabular}




\subsection{Pigment-Specific Phytoplankton Coefficients}

Tchla-specific absorption coefficient of phytoplankton at $440 \mathrm{~nm}, a^{*}$ phy (440), ranged between $0.023-0.061 \mathrm{~m}^{2} \mathrm{mg}^{-1}$ with an average of $0.045 \mathrm{~m}^{2} \mathrm{mg}^{-1}$ in Sognefjord. At $675 \mathrm{~nm}$, the coefficients ranged between $0.009-0.023 \mathrm{~m}^{2} \mathrm{mg}^{-1}$ with an average of $0.018 \mathrm{~m}^{2} \mathrm{mg}^{-1}$. In Trondheimsfjord, $a_{\text {phy }}^{*}$ (440) ranged between $0.031-0.039 \mathrm{~m}^{2} \mathrm{mg}^{-1}$ and $a_{\text {phy }}^{*}$ (675) within $0.017-0.018 \mathrm{~m}^{2} \mathrm{mg}^{-1}$ with average values of $0.035 \mathrm{~m}^{2} \mathrm{mg}^{-1}$ and $0.016 \mathrm{~m}^{2} \mathrm{mg}^{-1}$ respectively at 440 and $675 \mathrm{~nm}$.

Average coefficients of $a_{p h y}^{*}$ (675) were very similar in both the fjords. The coefficient $a^{*}$ phy (440) was more variable in Sognefjord than in Trondheimsfjord. Detailed statistics is provided in Table 2. Specific phytoplankton absorption spectra were regressed against Tchla to investigate any influence of pigment packaging in phytoplankton. Figure 7 presents the regression curves of $a_{\text {phy }}^{*}$ vs Tchla at different wavelengths. In Sognefjord, $a^{*}$ phy $(\lambda)$ showed a clear decreasing trend with increasing Tchla across blue-green bands $(412,443,490,510,555 \mathrm{~nm})$ and less markedly at $675 \mathrm{~nm}$ (red absorption band of Chla).
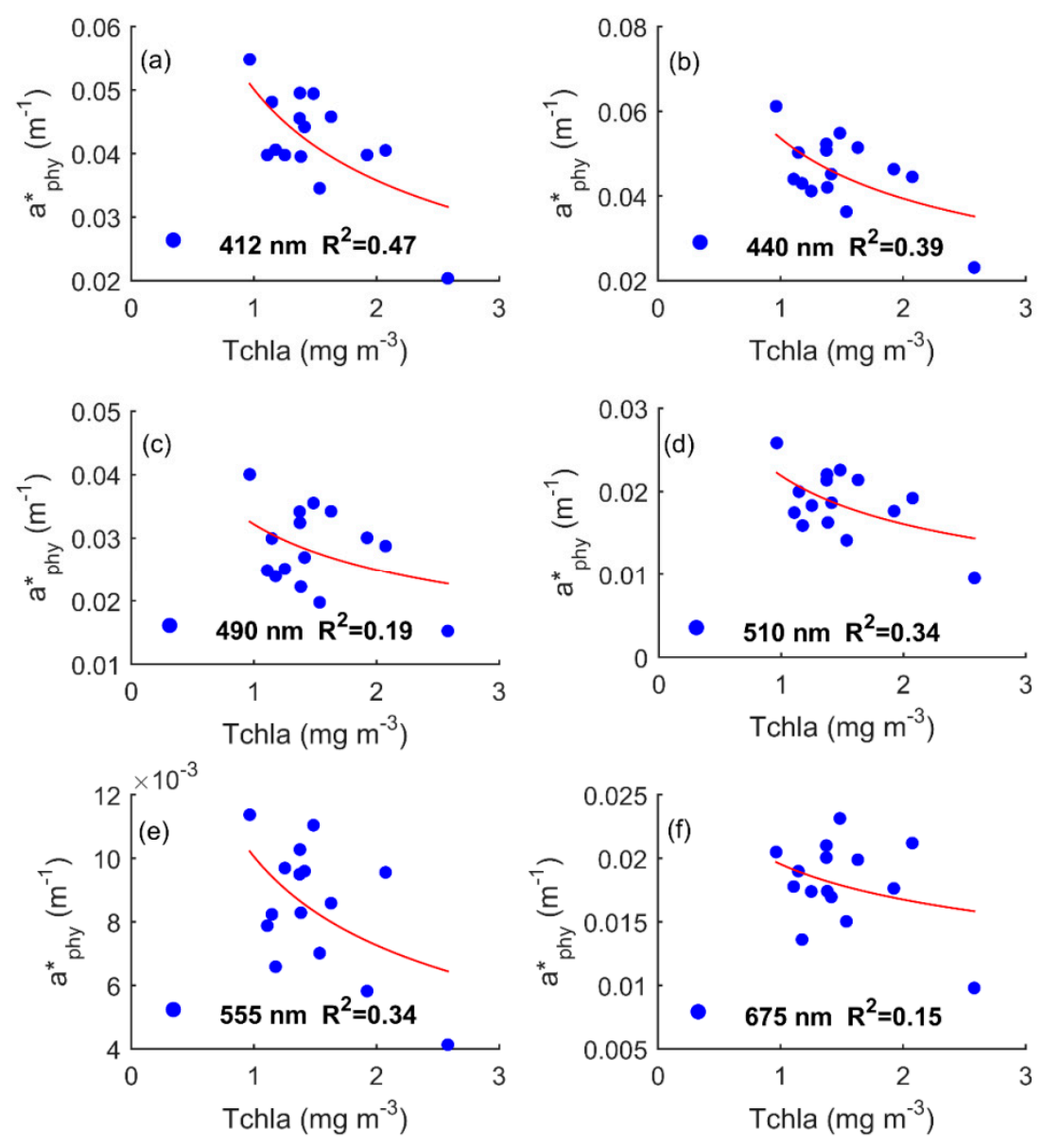

Figure 7. Variations in pigment-specific phytoplankton absorption coefficients, $a_{\text {phy }}^{*}(\lambda)$ as functions of Tchla (over a wavelength range $0.96-2.58 \mathrm{mg} \mathrm{m}^{-3}$ ), at selected wavelengths (a-f; 412, 440, 490, 510, 555, $675 \mathrm{~nm})$ in Sognefjord $(N=15)$. Decrease in $a^{*}$ phy with increase in Tchla at the blue-green wavelength bands indicating possible effects of pigment packaging. ( $N$ : number of data points).

\section{Discussion}

To examine the relationship between phytoplankton absorption coefficient and Tchla in oceanic waters power functions (Equation (8)) were first applied by [5] at mid and low latitudes, for waters ranging from oligotrophic to eutrophic. Bricaud et al. 1998 [3] then tested the power function using total particulate absorption coefficients and presented spectral variability in the parameters $A_{p}, A_{p h y}$, $E_{p}$, and $E_{p h y}$ in Equations (7) and (8). Considering the approach of $[3,5]$ as suitable, we parameterized 
total particulate $a_{p}(\lambda)$ and phytoplankton $a_{\text {phy }}(\lambda)$ absorption coefficients as functions of Tchla using power functions. Since phytoplankton dominated the particulate absorption coefficient in the fjords (case 2) under investigation, as is the case in oceanic waters (case 1), we attempted to test whether the parameterization in case 2 waters, such as the fjords, matches those provided for mid-and low-latitude waters ranging from oligotrophic to mesotrophic [3,5]. In high-latitude waters, parameterizations such as these have been reported in Atlantic polar waters [6], western Arctic Ocean [10], and in the Labrador Sea [9]. Earlier investigations in Norwegian coastal waters include those of $[4,16]$ in Samnangerfjorden.

The near-surface pigment and TSM concentrations were higher in Sognefjord while concentrations of CDOM were higher all along the Trondheimsfjord. Range of OAC concentrations observed in the two fjords under investigation are detailed in Table 2 and illustrated in Figure 2. OAC concentrations comparable to those encountered in Trondheimsfjord have been reported in Norwegian coastal water [4]. Chla concentration range in Sognefjord was comparable to that of [6] (0.08-5.00 $\left.\mathrm{mg} \mathrm{m}^{-3}\right)$ in the north polar Atlantic region. Near-surface spring Chla concentrations in the Labrador Sea varied between 0.60 to $9.6 \mathrm{mg} \mathrm{m}^{-3}$ with an average concentration of $2.2 \pm 2.7 \mathrm{mg} \mathrm{m}^{-3}$.

The dominant influence of phytoplankton on the total particulate absorption is also evident from the Chla peaks in the blue and red wavebands in the total particulate absorption spectra (Figure 3). In comparison, the percentage contributions of phytoplankton to $a_{p}(\lambda)$ at $440 \mathrm{~nm}$ were higher (90-97\%) in Trondheimsfjord than in Sognefjord (57-95\%). In Sognefjord, minimum $(57 \%)$ phytoplankton contribution was observed in the inner-fjord while maximum at stations in the outer-fjord (84-94\%). Dominant contribution of phytoplankton pigments to $a_{p}(\lambda)$ has earlier been reported in the high-latitude waters. The authors of [6] observed, on average, $74 \%$ contribution by phytoplankton pigments at $442 \mathrm{~nm}$ (Chla ranging from $0.08-5.00 \mathrm{mg} \mathrm{m}^{-3}$ ) in the north polar Atlantic region, while [4] reported $83 \%$ contribution to $a_{p}(\lambda)$ in Norwegian coastal waters (Chla ranging from $\left.0.82-1.94 \mathrm{mg} \mathrm{m}^{-3}\right)$. The two coefficients correlated strongly in Sognefjord $\left(\mathrm{R}^{2}(412)=0.92\right.$, $\left.R^{2}(443)=0.96, R^{2}(490)=0.96, R^{2}(555)=0.86, R^{2}(675)=0.98\right)$ and Trondheimsfjord $\left(R^{2}(412)=0.97\right.$, $\left.R^{2}(443)=0.99, R^{2}(490)=0.99, R^{2}(555)=0.98, R^{2}(675)=0.99\right)$. The increased scatter at $555 \mathrm{~nm}$ in Sognefjord is however noteworthy.

The contribution of non-algal particulate absorption to total absorption coefficient varied over a wider range in Sognefjord (with an average contribution of $20 \% \pm 9 \%$ ) than in Trondheimsfjord $(5 \% \pm 2 \%)$. The percentage ratios $\left(a_{n a p} / a_{p}\right)$ were higher in Sognefjord $(5-43 \%)$ than in Trondheimsfjord (3-10\%). This could be attributed to high concentrations of ISM reported in Sognefjord [17] through influx of glacial meltwater upstream, introducing inorganic sediments, also known as glacial flour, into the fjord $[26,27]$. Contributions of NAP to total particulate absorption was three times higher than that of phytoplankton (in the ratio 1:3) in the Atlantic polar waters [6] and two times higher (in the ratio 1:2) in the western Arctic Ocean. In the fjords under investigation, however, percentage contributions of the non-algal particles to $a_{p}(\lambda)$ at $440 \mathrm{~nm}$ was lower than that of phytoplankton pigments. Similar percent contribution pattern was observed in the western Arctic Ocean [10].

The general trends in the variability of, $a_{p}(\lambda)$ and $a_{p h y}(\lambda)$ coefficients at wavelengths corresponding to the blue $(440 \mathrm{~nm})$ and red $(675 \mathrm{~nm})$ Chla absorption peaks are presented in Figure 5 . The coefficients $\mathrm{a}_{\mathrm{p}}$ (440) and $\mathrm{a}_{\mathrm{phy}}$ (440) correlated well with Tchla in Trondheimsfjord (Equations (13) and (14)) resulting in higher coefficients of determination, $R^{2}=0.84$ and $R^{2}=0.85$, respectively. The $R^{2}$ in Sognefjord (Equations (9) and (10)) however, were comparatively low, 0.54 and 0.57, respectively. Including the inner Sognefjord stations in the analysis, did increase the $\mathrm{R}^{2}$ but the coefficients (Equations (11) and (12)) did not match closely. In Trondheimsfjord the coefficients of determination were lower as compared to those of [3], obtained for low- and mid-latitude waters. However, the coefficients were comparable to those reported in the western Arctic Ocean [10]. Those of Sognefjord were the lowest compared to the coefficients reported in the studies considered here in discussion. The variations of $a_{p}$ (443) and $a_{p h y}$ (443) appeared nearly parallel in Figure 3. The closely matching exponents $A_{p}, A_{p h y}$ and $E_{p}, E_{p h y}$ in Trondheimsfjord (Equations (13) and (14)) suggested proportional contribution by non-algal particles to the particulate absorption coefficient. Due to the 
observed intra-site variability the data was not pooled together and spectral A and E coefficients were determined for each of the fjords.

In Sognefjord, the $E_{p}(\lambda)$ and $E_{p h y}(\lambda)$ spectral forms (Figure 6) when compared to those in literature, were comparable to those obtained for Norwegian coastal waters by [4] (Tchla ranging between $0.82-1.94 \mathrm{mg} \mathrm{m}^{-3}$ ) and north Atlantic polar waters by [6] (Chla ranging between $0.08-5.0 \mathrm{mg}$ $\mathrm{m}^{-3}$ ). However, the spectra in Trondheimsfjord (Figure 6) resembled spectral shapes reported by [3] obtained for the mid and low latitude oligotrophic waters in the $550-650 \mathrm{~nm}$ spectral domain.

When the inner Sognefjord stations (highlighted in red in Figure 2A) covering a wider Tchla range $\left(0.96\right.$ to $\left.7.45 \mathrm{mg} \mathrm{m}^{-3}\right)$, are included in the parameterization, the spectral characteristics in $E_{p}(\lambda)$ and $E_{p h y}(\lambda)$ differ widely from the earlier parameterization. The magnitude differences in the two spectra reduce significantly (Figure 6). In their study, the authors of [10] also noted that the trends in $a_{\text {phy }}(\lambda)$ versus Tchla depart strongly from those of others especially at Chla less than $2.0 \mathrm{mg} \mathrm{m}^{-3}$. Phytoplankton absorption depends on a number of factors, such as pigment composition, concentration, packaging, cell size, light availability, etc. The differences in the $E_{p}$ and $E_{p h y}$ spectra can therefore be attributed to the aforementioned factors. The authors of [4] attributed differences in the coefficients to pigment packaging, high phaeopigment concentration, and differences in methods of pigment bleaching.

In comparison, modelled Tchla values matched the measured concentrations better in Trondheimsfjord than in Sognefjord. In Sognefjord, the parameterization developed by excluding the inner-fjord stations performed better (higher coefficients of determination, in Table 3) than the one developed including the inner-fjord stations. This could be attributed to the increased \% contribution of NAP to the total particulate absorption coefficient in the inner fjord. As discussed earlier, Sognefjord is highly influenced by glacial meltwater rich in inorganic sediments referred to as glacial flour [17]. In contrast, the parameterization developed for Trondheimsfjord (relatively low concentrations of ISM and $\%$ NAP) performed equally well in the estimation of Tchla (Table 3), both from $a_{p}(\lambda)$ and $a_{\text {phy }}(\lambda)$.

Additional peaks and shoulders were observed between the primary $(\sim 440 \mathrm{~nm})$ and the secondary $(\sim 675 \mathrm{~nm})$ Chla absorption maxima in both $a_{p}(\lambda)$ and $a_{p h y}(\lambda)$. These additional peaks indicated presence of pigments other than Chla. Absorption peaks between 600-650 and 650-700 nm were evident in both total particulate and phytoplankton absorption spectra in Sognefjord and Trondheimsfjord. The authors of $[4,16]$ proposed absorption by phycobiliproteins responsible for shoulders between 600 and $640 \mathrm{~nm}$. Phycocyanin found in cyanobacteria is known to have absorption peak at $620 \mathrm{~nm}$ [2].

The ranges of coefficients of $a^{*}$ phy (440) in both Sognefjord and Trondheimsfjord are presented in Table 2. The variations of $a_{p h y}^{*}(\lambda)$ as a function of Tchla at wavelengths corresponding to the blue-green channels are presented in Figure 7. Despite visible scatter, $a^{*}$ phy $(\lambda)$ exhibited a clear decreasing trend with increase in Tchla. The coefficients of determination decreased from 412 to 440 to $512 \mathrm{~nm}$ (0.47, 0.39 , and 0.34 respectively) while the variations $a^{*}$ phy $(\lambda)$ as a function of Tchla at $490 \mathrm{~nm}$ exhibited increased scatter $\left(R^{2}=0.2\right)$. In Trondheimsfjord, no such decrease in the pigment-specific coefficient curves were evident (not shown here).

The authors of [28] suggested the possibility that Tchla dependency of $a^{*}$ phy $(\lambda)$ could differ between regions. This holds true in our case as no inverse relation between $a^{*}{ }_{p h y}(\lambda)$ and Tchla was evident in Trondheimsfjord suggesting zero or least influence of pigment packaging on the cell's absorption efficiency. The authors of [29] also reported no dependency of $a^{*}$ phy (443) over a similar Chla concentration range, $0.05-2.5 \mathrm{mg} \mathrm{m}^{-3}$ for the Gulf of Maine and Georges bank regions in the western north Atlantic. The authors of [5] proposed two main causes resulting in decrease of $a^{*}$ phy $(\lambda)$ with increasing Tchla:

i. $\quad$ an increasing package effect and

ii. inverse covariation between the relative abundance of accessory pigments ( $\mathrm{chl} b, \mathrm{chl} c$, and carotenoids) and Tchla. 


\section{Conclusions}

Although the fjords under investigation share similar geographical conditions, they exhibit very different bio-optical characteristics. Sognefjord being influenced by glacial meltwater influx upstream, is influenced by high non-algal particulate matter concentrations that contribute significantly to the total absorption coefficient, along the entire fjord transect. However, the percentage contribution of phytoplankton to the total absorption coefficient exceeded those of non-algal particles. In Trondheimsfjord, on the other hand, phytoplankton contributed about $90-97 \%$ to the total particulate absorption coefficient. As a result, spectral $a_{p}$ and $a_{\text {phy }}$ parameterization curves deviate significantly from each other in Sognefjord while those matched closely in Trondheimsfjord. Tchla retrieval from $a_{p}$ resulted in better coefficients of determination than from $a_{p h y}(\lambda)$ in Sognefjord. This could be attributed to factors such as pigment composition and package effects also evident from the variations of $a_{\text {phy }}^{*}(\lambda)$ as a function of pigment concentration (Tchla).

In fjords influenced by glacial meltwater influx such as the Sognefjord, relatively high percentage contributions of non-algal particles, especially inorganic sediments (glacial flour) could be a major source contributing to errors and uncertainties in accurate retrievals of biogeochemical parameters. Their contributions to the total particulate absorption therefore need to be taken into consideration and accounted for in bio-optical models and semi analytical retrievals. Additionally, colored dissolved organic matter (CDOM) contributes significantly and dominates the total absorption in the blue wavelength domain in the two fjords under investigation. The findings of the investigation necessitate in situ observations in the development and establishment of local bio-optical algorithms for accurate retrievals of biogeochemical parameters. With increase in high resolution and hyperspectral satellite missions, local parameterizations such as these can facilitate effective monitoring of complex coastal ecosystems such as the fjords, of high socio-economic and cultural value, constantly under anthropogenic influence.

Author Contributions: V.J.M. conceptualized the study, developed the methodology, performed formal analysis, visualized and prepared the initial draft. O.Z. acquired funding for resources, supervised and provided critical reviews and editing.

Funding: The study is part of the project, 'Coastal Ocean Darkening' (COD), funded by the ministry of science and culture of Lower Saxony, Germany (VWZN3175).

Acknowledgments: The authors are thankful to the master and crew onboard RV Heincke of HE448 and HE491 campaigns. The cruises were supported by the Alfred Wegener Institute (AWI) and the German Federal Ministry of Education and Research. Sincere thanks to Daniela Voss, Daniela Meier, Rohan Henkel, Jochen Wollschlaeger, Anna Friedrichs, Joeline Ezekiel, Kai Schwalfenberg, and Kathrin Dietrich for assistance in data collection and laboratory analysis of water samples. The support and cooperation with AWI, HZG, and NIVA is acknowledged. The authors are grateful for the feedback received from three anonymous reviewers.

Conflicts of Interest: The authors declare no conflict of interest. The funding sponsors had no role in the design of the study; in the collection, analyses, or interpretation of data; in the writing of the manuscript, and in the decision to publish the results.

\section{References}

1. Gordon, H.R.; Brown, O.B.; Evans, R.H.; Brown, J.W.; Smith, R.C.; Baker, K.S.; Clark, D.K. A semianalytic radiance model of ocean color. J. Geophys. Res. Atmos. 1988, 93, 10909-10924. [CrossRef]

2. Kirk, J.T. Light and Photosynthesis in Aquatic Ecosystems; Cambridge University Press: Cambridge, UK, 1994.

3. Bricaud, A.; Morel, A.; Babin, M.; Allali, K.; Claustre, H. Variations of light absorption by suspended particles with chlorophyll a concentration in oceanic(case 1) waters- analysis and implications for bio-optical models. J. Geophys. Res. 1998, 103, 31033-31044. [CrossRef]

4. Nima, C.; Frette, Ø.; Hamre, B.; Erga, S.R.; Chen, Y.-C.; Zhao, L.; Sørensen, K.; Norli, M.; Stamnes, K.; Stamnes, J.J. Absorption properties of high-latitude norwegian coastal water: The impact of cdom and particulate matter. Estuar. Coast. Shelf Sci. 2016, 178, 158-167. [CrossRef] 
5. Bricaud, A.; Babin, M.; Morel, A.; Claustre, H. Variability in the chlorophyll-specific absorption coefficients of natural phytoplankton: Analysis and parameterization. J. Geophys. Res. Oceans 1995, 100, 13321-13332. [CrossRef]

6. Stramska, M.; Stramski, D.; Hapter, R.; Kaczmarek, S.; Stoń, J. Bio-optical relationships and ocean color algorithms for the north polar region of the atlantic. J. Geophys. Res. Oceans 2003, 108. [CrossRef]

7. Dierssen, H.; Smith, R. Bio-optical properties and remote sensing ocean color algorithms for antarctic peninsula waters. J. Geophys. Res. Oceans 2000, 105, 26301-26312. [CrossRef]

8. Sathyendranath, S.; Cota, G.; Stuart, V.; Maass, H.; Platt, T. Remote sensing of phytoplankton pigments: A comparison of empirical and theoretical approaches. Int. J. Remote Sens. 2001, 22, 249-273. [CrossRef]

9. Cota, G.F.; Harrison, W.G.; Platt, T.; Sathyendranath, S.; Stuart, V. Bio-optical properties of the labrador sea. J. Geophys. Res. Oceans 2003, 108. [CrossRef]

10. Matsuoka, A.; Huot, Y.; Shimada, K.; Saitoh, S.-I.; Babin, M. Bio-optical characteristics of the western arctic ocean: Implications for ocean color algorithms. Can. J. Remote Sens. 2007, 33, 503-518. [CrossRef]

11. Garcia, V.M.T.; Signorini, S.; Garcia, C.A.E.; McClain, C.R. Empirical and semi-analytical chlorophyll algorithms in the south-western atlantic coastal region (25-40 s and 60-45 w). Int. J. Remote Sens. 2006, 27, 1539-1562. [CrossRef]

12. Lapucci, C.; Rella, M.A.; Brandini, C.; Ganzin, N.; Gozzini, B.; Maselli, F.; Massi, L.; Nuccio, C.; Ortolani, A.; Trees, C.C. Evaluation of empirical and semi-analytical chlorophyll algorithms in the ligurian and north tyrrhenian seas. J. Appl. Remote Sens. 2012, 6, 063565. [CrossRef]

13. Marra, J.; Trees, C.C.; O’Reilly, J.E. Phytoplankton pigment absorption: A strong predictor of primary productivity in the surface ocean. Deep Sea Res. Part I Oceanogr. Res. Pap. 2007, 54, 155-163. [CrossRef]

14. Murray, C.; Markager, S.; Stedmon, C.A.; Juul-Pedersen, T.; Sejr, M.K.; Bruhn, A. The influence of glacial melt water on bio-optical properties in two contrasting greenlandic fjords. Estuar. Coast. Shelf Sci. 2015, 163, 72-83. [CrossRef]

15. Salvanes, A.G.V.; Aksnes, D.L.; Giske, J. Ecosystem model for evaluating potential cod production in a west norwegian fjord. Mar. Ecol. Prog. Ser. 1992, 90, 9-22. [CrossRef]

16. Hamre, B.; Frette, Ø.; Erga, S.R.; Stamnes, J.J.; Stamnes, K. Parameterization and analysis of the optical absorption and scattering coefficients in a western norwegian fjord: A case ii water study. Appl. Opt. 2003, 42, 883-892. [CrossRef] [PubMed]

17. Mascarenhas, V.; Voß, D.; Wollschlaeger, J.; Zielinski, O. Fjord light regime: Bio-optical variability, absorption budget, and hyperspectral light availability in sognefjord and trondheimsfjord, norway. J. Geophys. Res. Oceans 2017, 122, 3828-3847. [CrossRef]

18. Zielinski, O. Station List and Links to Master Tracks in Different Resolutions of Heincke Cruise HE448, Bremerhaven-Trondheim, 2015-07-07-2015-07-30; Alfred Wegener Institute, Helmholtz Center for Polar and Marine Research: Bremerhaven, Germany, 2015.

19. Zielinski, O.; Rohardt, G. Physical Oceanography during Heincke Cruise HE448; Alfred Wegener Institute, Helmholtz Center for Polar and Marine Research: Bremerhaven, Germany, 2016.

20. Wurl, O.; Wisotzki, A. Physical Oceanography during Heincke Cruise HE491; Alfred Wegener Institute, Helmholtz Center for Polar and Marine Research: Bremerhaven, Germany, 2017.

21. Wurl, O. Station List and Links to Master Tracks in Different Resolutions of Heincke Cruise HE491, Bremerhaven-Trondheim, 2017-07-08-2017-07-27; Alfred Wegener Institute, Helmholtz Center for Polar and Marine Research: Bremerhaven, Germany, 2017.

22. Bowers, D.; Harker, G.; Stephan, B. Absorption spectra of inorganic particles in the irish sea and their relevance to remote sensing of chlorophyll. Int. J. Remote Sens. 1996, 17, 2449-2460. [CrossRef]

23. Roesler, C.; Stramski, D.; D'Sa, E.; Röttgers, R.; Reynolds, R.A. Spectrophotometric Measurements of Particulate Absorption Using Filter Pads. Available online: http:/ /ioccg.org/wp-content/uploads/2017/ 11/chapter_5_corrigendum.pdf (accessed on 19 June 2018).

24. Voß, D.; Meier, D.; Mascarenhas, V.J.; Friedrichs, A.; Zielinski, O. Absorbance measurements of total particulate and non-algal particulate matter during heincke cruise HE448 in sognefjord and trondheimsfjord, norway. J. Geophys. Res. Ocean. 2018, 122, 3828-3847. [CrossRef]

25. Mascarenhas, V.J.; Zielinski, O. Spectral particulate absorption properties in sognefjord and trondheimsfjord, norway. In Proceedings of the OCEANS 2017-Aberdeen, Aberdeen, UK, 19-22 June 2017; pp. 1-6. 
26. Holinde, L.; Zielinski, O. Bio-optical characterization and light availability parameterization in uummannaq fjord and vaigat-disko bay (west greenland). Ocean Sci. 2016, 12, 117-128. [CrossRef]

27. Lund-Hansen, L.C.; Andersen, T.J.; Nielsen, M.H.; Pejrup, M. Suspended matter, chl-a, cdom, grain sizes, and optical properties in the arctic fjord-type estuary, kangerlussuaq, west greenland during summer. Estuar. Coasts 2010, 33, 1442-1451. [CrossRef]

28. Carder, K.L.; Hawes, S.; Baker, K.; Smith, R.; Steward, R.; Mitchell, B. Reflectance model for quantifying chlorophyll a in the presence of productivity degradation products. J. Geophys. Res. Oceans 1991, 96, 20599-20611. [CrossRef]

29. Hoepffner, N.; Sathyendranath, S. Bio-optical characteristics of coastal waters: Absorption spectra of phytoplankton and pigment distribution in the western north atlantic. Limnol. Oceanogr. 1992, 37, 1660-1679. [CrossRef]

(C) 2018 by the authors. Licensee MDPI, Basel, Switzerland. This article is an open access article distributed under the terms and conditions of the Creative Commons Attribution (CC BY) license (http://creativecommons.org/licenses/by/4.0/). 